a Universidade do Estado do Rio de Janeiro, Instituto de Biologia, Pós-graduação em Biologia Vegetal, Maracanã, CEP 20550-013, Rio de Janeiro-RJ, Brasil.

b Fundação Oswaldo Cruz, Laboratório de Produtos Naturais, Farmanguinhos, Rua Sizenando Nabuco 100, Manguinhos, CEP 21041-250, Rio de Janeiro-RJ, Brasil.

*E-mail: davysonmoreira@ hotmail.com

Recebido: 22 de Março de 2021

Aceito: 22 de Março de 2021

Publicado online: 6 de outubro de 2021

\section{Development and Validation of an Analytical Method to Quantify Bioactive Neolignans of Piper rivinoides Kunth Extracts}

\author{
Desenvolvimento e Validação de Método Analítico para Quantificação de \\ Neolignanas Bioativas em Extratos de Piper rivinoides Kunt.
}

Jéssica Sales Felisberto, ${ }^{a, b}$ André Mesquita Marques, ${ }^{b}$ Davyson de Lima Moreira, ${ }^{a, b, *(D)}$

\begin{abstract}
Piper rivinoides Kunth (Piperaceae) is a native species from Brazil and is registered from North to South. Investigations about the chemistry of $P$. rivinoides indicate the presence of bioactive benzofuran neolignans eupomatenoid-5 (EUP-5), eupomatenoid-6 (EUP-6) and conocarpan (CNC) in its extract. Therefore, the extract of $P$. rivinoides Kunth, rich in neolignans, has the potential to become a phytotherapeutic product. A newly High-performance Liquid Chromatography coupled to Diode-Array Detector (HPLC-DAD) method for simultaneous determination and quantification of EUP-5, EUP-6 and $\mathrm{CNC}$ was developed and validated in this work. A modified-silica based column C-18 (250 mm x 4.6 $\mathrm{mm}, 5 \mu \mathrm{m})$ with mobile phase composed by acetonitrile and ultrapure water $(80: 20 \mathrm{v} / \mathrm{v})$ was used, along with temperature of $50{ }^{\circ} \mathrm{C}$, flow rate at $1 \mathrm{~mL} / \mathrm{min}$, injection volume of $20 \mu \mathrm{L}$ and total analysis time of $8 \mathrm{~min}$. The method was validated, showing to be selective and linear for the concentration ranges 3.125 - $100 \mu \mathrm{g} / \mathrm{mL} ; 3.125-75 \mu \mathrm{g} / \mathrm{mL}$ and $1-20 \mu \mathrm{g} / \mathrm{mL}$ for EUP-5, EUP-6 and CNC, respectively; precise $(\mathrm{CV}<2.0 \%)$; exact $(\mathrm{CV}<5.0 \%)$; robust $(\mathrm{CV}<3.0 \%)$, with recovery values close to $100 \%$ and limits of quantification and detection that vary in the range of $50-100 \mathrm{ng} / \mathrm{mL}$ and $25-37.5 \mathrm{ng} / \mathrm{mL}$. The method developed and validated is unprecedented and will contribute to adequate phytochemical analysis, as well as to the establishment of quality control parameters for extracts of $P$. rivinoides.
\end{abstract}

Keywords: HPLC-DAD; eupomatenoid-5; eupomatenoid-6; conocarpan; phytochemical analysis.

\section{Introduction}

Piper rivinoides Kunth (Piperaceae) popularly known as “aperta-ruão", "murta”, "ruão" ou "betis branco" is a native species from Brazil, registered from North to South. ${ }^{1}$ This species is described as a glabrous, ciophile shrub, with a height between 3-6 m and a well-lignified stem; shiny, ovate, and symmetrically based leaves; inflorescences and infructescence of the erect spike, showy and trigonal nature that is used as food for several animals. ${ }^{2}$ Ethnobotanical studies for P. rivinoides in Brazil describe its liturgical name "Èwé Boyí Funfun" and application of this plant for purification bath in Brazilian religious rituals originating from African matrices. The members of the respective religions also make medicinal uses of $P$. rivinoides for the treatment of wounds, ulcers, hemorrhages and for oral problems. ${ }^{3-6}$

Studies on the chemistry of the secondary metabolism of $P$. rivinoides describe that the plant is rich in essential oils and compounds derived from the shikimic acid pathway. ${ }^{7-10}$ Investigations on biological activities of special metabolites synthesized by $P$. rivinoides point out their pharmacological potential against Micobacterium tuberculosis, Leishmania amazonensis, ${ }^{8}$ Candida albicans, ${ }^{10}$ antinociceptive action, ${ }^{11}$ and cytotoxic effect against oral squamous cell carcinoma. ${ }^{12}$

In an investigation on the composition of the crude extract of $P$. rivinoides, ${ }^{9}$ it was possible to isolate and identify bioactive benzofuran neolignans (Figure 1), as well as demonstrated the potential of these compounds against strains of Candida albicans and L. amazonensis. Literature records also showed the bioactive potential of benzofuran neolignans such as eupomatenoid-5 (anti-tuberculosis, ${ }^{13,14}$ antioxidant, ${ }^{15}$ leishmanicide, ${ }^{16,17}$ anticarcinogenic, ${ }^{18}$ trypanocide. ${ }^{19,20}$ ); eupomatenoid-6 (larvicide, ${ }^{21}$ antibacterial, ${ }^{22}$ antifungal. ${ }^{23-25}$ ); and conocarpan (anti-tuberculosis, ${ }^{13}$ antibacterial, ${ }^{22}$ antinociceptive. ${ }^{26}$ ). 
Therefore, it is clear that the extract of $P$. rivinoides has great potential to be a source of future phytotherapeutic product based on neolignans. In order to contribute to the quality control process, it is mandatory to demonstrate the quality and authenticity of bioactive compounds by comparability, traceability, and reliability of analytical data ${ }^{27}$. Thus, this work aimed to develop and validate a method by HPLC-DAD to simultaneously quantify the bioactive neolignans eupomatenoid-5 (EUP-5), eupomatenoid-6 (EUP-6) and conocarpan (CNC) in the crude extract of $P$. rivinoides. In addition, for demonstration of the efficiency of the method, three distinct samples of $P$. rivinoides extract collected in the Tijuca Forest were quantified.

\section{Experimental Procedure}

\subsection{Materials}

\subsubsection{Plant material}

Fresh leaves of Piper rivinoides Kunth were collected in January, April and July 2019 at Tijuca National Park, Rio de Janeiro/RJ (SISBIO n. 57296-1). The botanical identification was carried out by Dr. Elsie Franklin Guimarães of the Botanical Garden Research Institute of Rio de Janeiro (IPJBRJ), and voucher samples were deposited at the Herbarium of the State University of Rio de Janeiro (HRJ) under registration number 13404. The collected leaves were dried in an oven equipped with eight $1000 \mathrm{~W}$ lamps $\left(\sim 40^{\circ} \mathrm{C}\right)$ for $24 \mathrm{~h}$ at HRJ. After drying, the leaves were grounded in a knife mill. After processing, the dried and grounded leaves were stored in a freezer at $-18^{\circ} \mathrm{C}$ until the moment of extraction.

\subsubsection{Reagents}

The solvents used for the extraction were ethanol and methanol analytical grade $\left(\right.$ Tedia, Brazil ${ }^{\circledR}$ ) and ultrapure water MiliQ (Millipore, São Paulo, Brazil) obtained in the laboratory.
For chromatographic analyzes, acetonitrile used was HPLC grade, Ethanol, and Methanol purchased were analytical grade, all from Tedia, Brazil. For evaluation of robustness the acetonitrile used was the Merck ${ }^{\circledR}$ brand. The purified water used was from a Milli-Q system (Millipore, São Paulo, Brazil) and the glacial acetic acid was purchased from Sigma-Aldrich, Brazil. Each pure and isolated neolignane, previously described, with purity $>98 \%$, HPLC grade, was stored as stock solutions $(400.00 \mu \mathrm{g} / \mathrm{mL})$ in amber vials, under refrigeration $\left(0-5{ }^{\circ} \mathrm{C}\right) .{ }^{9}$

\subsubsection{Equipment}

The development and validation of the analytical method were performed in HPLC-DAD (Shimadzu, Nexera $\mathrm{XR}^{\circledR}$ ), equipped with binary pump LC-20AD, automatic injector (SIL-20AF), oven CTO-20A, detection system by DAD-UV-VIS APD-20MA, degasser (DGU20A) and controller (CBM-20A). The chromatographic data were analyzed using Shimadzu LabSolutions ${ }^{\circledR}$ software. The ultrasonic bath used was the Unique (USC1400) (Unique, Brazil) with $2.8 \mathrm{~L} \mathrm{x} 40 \mathrm{kHz} \times 120 \mathrm{~W}$.

\subsection{Methods}

\subsubsection{Chromatographic parameters}

Ascentis C-18 column (250 mm x $4.6 \mathrm{~mm}$ i.d., 5 $\mu \mathrm{m}$ particle size, Supelco, Brazil) was used. The mobile phase was composed by acetonitrile and ultrapure water 80:20 (v/v), degassed in an ultrasound bath before use. The analyzes were performed at a temperature of $50{ }^{\circ} \mathrm{C}$ with a constant mobile phase flow rate at $1 \mathrm{~mL} / \mathrm{min}$ and standard and sample injection volume of $20 \mu \mathrm{L}$. The analyzes were performed in triplicate, in a total time of $8 \mathrm{~min}$ and in the highest UV absorption of each compound. The three neolignans were identified in the extracts by co-injection, as well as retention time and UV spectrum comparison.<smiles>C/C=C/c1ccc2oc(-c3ccc(O)c(OC)c3)c(C)c2c1</smiles>

(1)

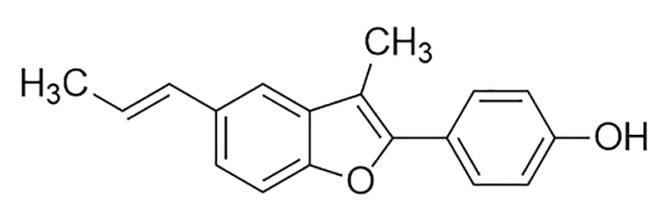

(2)<smiles>C/C=C/c1ccc2c(c1)[C@H](C)[C@H](c1ccc(O)cc1)O2</smiles>

(3)

Figure 1. Structural representation of benzofuran neolignans eupomatenoid-5 (1), eupomatenoid-6 (2) and conocarpan (3) from Piper rivinoides Kunth 


\subsubsection{Extract preparation}

The dried and grounded leaves $(2 \mathrm{~g})$ were submitted to extraction with a solution $(10 \mathrm{~mL})$ composed of ethanol and ultrapure water 9: $1(\mathrm{v} / \mathrm{v})$ and submitted to an ultrasonic bath for accelerated extraction. ${ }^{9,28}$ The condition for extracting the plant material were temperature of 22 ${ }^{\circ} \mathrm{C}$, frequency of $40 \mathrm{kHz}$ and power of $120 \mathrm{~W}$ for $15 \mathrm{~min}$. The extract was filtered on qualitative filter paper (Merck Millipore, Brazil) and the filtrate was collected and then left to air dried flow for solvent evaporation in a chapel. After evaporation until constant weight, the resulting dry extract was weighed and stored under refrigeration $\left(0-5{ }^{\circ} \mathrm{C}\right)$ until the moment of analysis.

\subsubsection{Sample preparation}

All HPLC-DAD analyses were done with a solution of $10.00 \mathrm{mg} / \mathrm{mL}$ of crude hydroalcoholic extract in methanol. Solubilization was done in ultrasonic bath (Unique USC1400, Brazil) for $10 \mathrm{~min}$. The diluted extract was filtered with a $0.45 \mu \mathrm{m}$ filter (Sigma-Aldrich ${ }^{\circledR}$, Brazil) and subjected to HPLC-DAD analysis.

\subsubsection{Parameters determination for method validation}

Validation procedures were performed according to analytical guidelines, including selectivity, linearity, precision, accuracy, recovery, limit of quantification $(L O Q)$, limit of detection (LOD) and robustness. ${ }^{29,30}$

Individual calibration curves were done due to the differences in concentration for each benzofuran neolignan in the $P$. rivinoides extracts. Thus, the values were set to EUP-5 as $3.12 ; 6.25 ; 12.50 ; 25.00 ; 50.00$; and $100.00 \mathrm{mg} /$ mL; EUP-6 3.12; 6.25; 12.50; 25.00; 50.00; and $75.00 \mathrm{mg} /$ $\mathrm{mL}$ and CNC 1.00; $2.00 ; 4.00 ; 8.00 ; 10.00$; and $20.00 \mu \mathrm{g} /$ $\mathrm{mL}$. Work solutions (WS) were obtained by serial dilutions from the SS. Linearity was verified by three calibration curves obtained in three different days for each neolignan. Then, the correlation coefficient $r$ or the determination coefficient $r^{2}$ was calculated, which are parameters that allow an estimate of the quality of the obtained curve. The differences between the experimental values and the theoretical values estimated by fitting a linear model to the calibration data were used to determine homoscedasticity.

Precision was assessed at two levels, repeatability (intra-day) and intermediate precision (inter-day), on three consecutive days, for solutions in the minimum, average and maximum concentration of the analytical curve, with three replicates each. The solutions were analyzed and then, the relative standard variation (RSD) was calculated (values above $5 \%$ were not accepted). ${ }^{29,30}$

Accuracy was assessed at six different concentration levels for each neolignan and determined by comparing the corresponding experimental and theoretical concentrations, that is, concentrations derived from the analytical curve, with values less than $85 \%$ and greater than $115 \%$ not being accepted. ${ }^{29,30}$

Recovery of the extraction procedure was evaluated at two concentration levels for each neolignan from WS: 2.00 and $10.00 \mathrm{mg} / \mathrm{mL}$ for CNC; 6.25 and $50.00 \mathrm{mg} / \mathrm{mL}$ for EUP-5 and EUP-6. Standard samples of the crude hydroalcoholic extracts spiked with neolignans solutions were subsequently extracted. The recovery calculation was performed according to the area of the extracted and nonextracted pattern.

Robustness was determined for the lowest and highest concentrations of the analytical curve, using WS, being 3.12 and $100.00 \mu \mathrm{g} / \mathrm{mL}$ for EUP-5; 3.12 and 75.00 $\mathrm{mg} / \mathrm{mL}$ for EUP- 6 and 1.00 and $20.00 \mathrm{mg} / \mathrm{mL}$ for the CNC. Robustness was based on the influence of five analytical parameters (flow of the mobile phase, oven temperature, concentration of acetonitrile in the mobile phase, UV wavelength and acetonitrile trademark) and their respective variations.

$L O D$ and $L O Q$ were obtained by evaluating the signal-to-noise ratio (3:1 and 10:1, respectively) of known concentrations and by successive serial dilutions applied to a SS of $400.00 \mu \mathrm{g} / \mathrm{mL}$ of each neolignan.

\subsubsection{Statistical analysis}

The results are noted as mean \pm standard deviation $(\mathrm{M} \pm \mathrm{SD})$. The data to compare intra-day and inter-day precision were processed using the Tukey test (ANOVA) with 5\% significance level $(p<0.05)$ (STATISTICA software version 10; StartSoft Inc., Tulsa, USA).

\section{Results and Discussion}

The analytical methodology was validated in accordance with the recommendations of the Analytical Methods Validation Guide DOQ-CGCRE-008/2016 from Brazilian National Institute of Metrology, Quality and Technology (INMETRO) and in accordance with The International Council for Harmonization of Technical Requirements for Pharmaceuticals for Human Use (ICH).

In the development of an adequate chromatographic condition for the separation of the three benzofuran neolignans by HPLC-DAD, it was sought to use simpler and reproducible conditions that could be performed quickly, with lower cost and greater efficiency. We used acetonitrile/acidified ultrapure water in different combination and different $\mathrm{pH}$ values of the aqueous solution; different flow rate and temperature to obtain better resolution. Best conditions were achieved as mentioned in Method, 2.2.2 Chromatographic parameters. 
The developed method is quite advantageous, since the total analysis time is $8 \mathrm{~min}$ and by this mean, there is less expense of solvents and greater time optimization, which makes it possible to carry out many analyzes in a single day. Retention times (Rt) were registered at $6.80 \mathrm{~min}$ for EUP5; 6.03 min for EUP-6 and $4.60 \mathrm{~min}$ for CNC. The highest UV absorption for EUP-5, EUP-6 and CNC neolignans was registered at 256, 256 and $264 \mathrm{~nm}$, respectively. The identification of each neolignan in the chromatogram of the crude extract was possible by co-injection, comparing the Rt and UV spectrum obtained in the chromatogram of pure compounds.

\subsection{Selectivity and linearity}

The choice of the mobile phase was adequate for separation of the signals with great resolution (> $3.0)$, signal symmetry $(\sim 1)$ and retention factor $(>2.7)$, demonstrating the complete separation between the neolignans even in the presence of other components of the crude extract, suggesting the selectivity of the method proposed in this work: eupomatenoid-5 (Resolution Eup5-Eup6 $_{1}$ $=3.02$, Resolution $_{\text {Eup5-CNC }}=4.03$; signal symmetry 1.0 ; retention factor $=4.79)$; eupomatenoid-6 $\left(\right.$ Resolution $_{\text {Eup6- }}$ $\mathrm{CNC}=3.32$; signal symmetry 1.1 ; retention factor $=3.00$ ); conocarpan (signal symmetry 1.3 ; retention factor $=2.71$ ). The absence of interference in the detection window of the three neolignans confirms the selectivity of the method (Figures 2-A and 2-B).
Linearity was demonstrated from three analytical curves of six concentrations, obtained on three different days for each pure neolignan solution. In this case, when the slopes of the three curves are equal or remarkably close and the ratio between the two angular coefficients approaches to 1 , it means that the dispersion of the set of experimental points is smaller. Therefore, the lower the uncertainty of the regression coefficients, the method is linear. Figure 3 shows the results obtained in the linearity study of the method for the sample of $P$. rivinoides benzofuran neolignans. The analytical curves for EUP-5, EUP-6 and CNC showed positive linear correlation, with $r=0.999 ; 0.9998$ and 0.9990 , respectively. Residual analysis showed a homoscedastic distribution. The formulas obtained by linear regression and used to quantify the three neolignans in the extracts of $P$. rivinoides are: Eupomatenoid-5 $($ Concentration $=($ ABS $-26539 \pm$ 620) / $94138 \pm 147$ ); Eupomatenoid-6 (Concentration = (ABS - $28702 \pm 1049) / 170551 \pm 204)$, and Conocarpan $($ Concentration $=(\mathrm{ABS}-17341 \pm 493) / 67752 \pm 52)$; where concentration $=\mathrm{mg} / \mathrm{mL}$ and $\mathrm{ABS}=$ absorbance in $\mathrm{mAU}$.

\subsection{Precision}

The results obtained in the evaluation of the method precision (repeatability) and intermediate precision are shown in table 1 . The observed RSD were below the limit of $15 \%$ (INMETRO, 2016). Still, there was no variation between the intra-day average when compared with the interday average $(p<0.05)$. Therefore, the method developed is precise (INMETRO, 2016). ${ }^{29,30}$
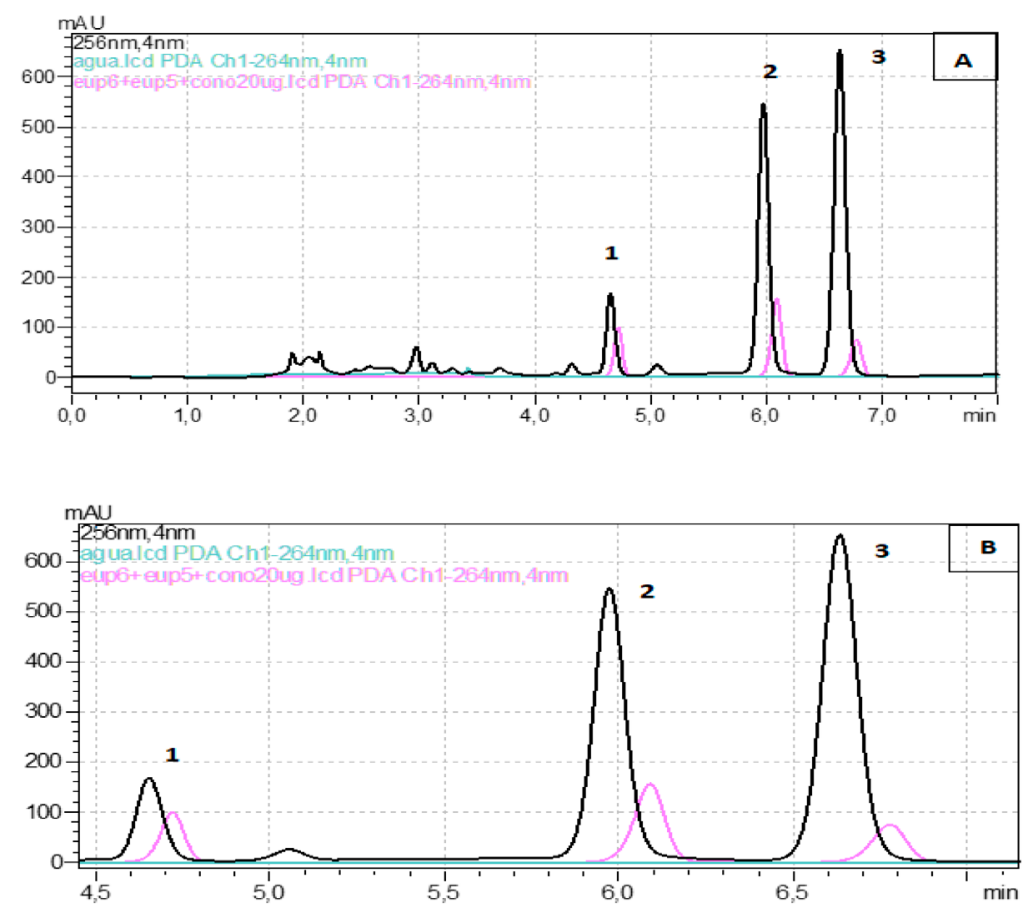

Figure 2. A - Chromatograms overlap of the blank sample (ultrapure water, blue); sample with pure compounds (pink) and crude extract of Piper rivinoides (black); B - Chromatograms amplification (Rt 4.5 - 7.2 min) of the Blank (water, blue) sample, sample with pure compounds (pink) and crude extract of Piper rivinoides (black); 1 = CNC, 2 = EUP-6, 3 = EUP-5. The signal shift is compatible with variations that can occur between different chromatographic runs 


\subsection{Accuracy}

The results obtained in the accuracy assessment were also satisfactory. It is possible to observe that the variations are, therefore, within the limits allowed by the validation regulation ( $85-115 \%)$, as well as values of RSD were less than $5.0 \%$. The results are shown in table 2 . Thus, the developed method can be considered accurate..$^{29,30}$

\subsection{Recovery}

Neolignan recovery was evaluated at two concentration levels (low and high) for each neolignan. The data are shown in table 3 . Recovery rates were greater than $80 \%$ and less than $115 \%$ for all concentration levels, therefore within legal specifications. ${ }^{29,30}$

\subsection{Robustness}

The robustness evaluation made it possible to affirm, based on the coefficient of variation data between the analyzes performed, that the changes applied in the analytical method had little influence on the average of the areas of both concentrations tested for the three analyzed neolignans. Therefore, the developed method is robust. The effects of the conditions of the tested parameters to assess the robustness of the neolignan analysis method are shown in table 4 .
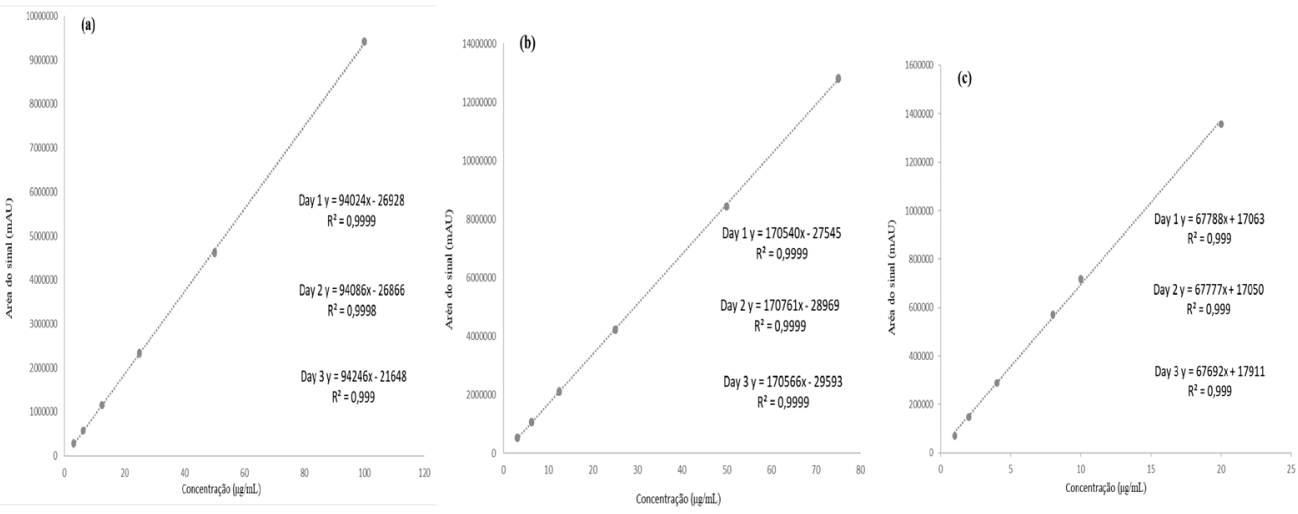

Figure 3. Analytical curves of the developed method for (a) eupomatenoid-5 in the concentration range $3.12-100.00 \mu \mathrm{g} / \mathrm{mL}$; (b) eupomatenoid-6 in the concentration range of 3.12-75.00 $\mu \mathrm{g} / \mathrm{mL}$; (c) conocarpan in the concentration range of $1.00-20.00 \mu \mathrm{g} / \mathrm{mL}$, with the respective determination coefficients $(\mathrm{n}=3)$. *Error bars can not be shown due to low RSD

Table 1. Results obtained in the analysis of the precision of the new analytical method for quantification of bioactive neolignans eupomatenoid-5, eupomatenoid-6 and conocarpan in crude extract of Piper rivinoides Kunth.

\begin{tabular}{|c|c|c|c|c|c|c|c|c|c|c|c|c|c|c|}
\hline \multicolumn{5}{|c|}{ Eupomatenoid-5 } & \multicolumn{5}{|c|}{ Eupomatenoid-6 } & \multicolumn{5}{|c|}{ Conocarpan } \\
\hline $\begin{array}{c}{[]} \\
\mu \mathrm{g} / \mathbf{m L}\end{array}$ & $\begin{array}{c}\mathbf{M} \\
(\mathbf{m A U})\end{array}$ & RSD\% & $\begin{array}{c}\mathbf{M} \\
(\mathbf{m A U})\end{array}$ & RSD\% & $\begin{array}{c}{[]} \\
\mu \mathrm{g} / \mathrm{mL}\end{array}$ & $\begin{array}{c}\mathbf{M} \\
(\mathbf{m A U})\end{array}$ & RSD\% & $\begin{array}{c}\mathbf{M} \\
(\mathbf{m A U})\end{array}$ & RSD\% & $\begin{array}{c}{[]} \\
\mu \mathrm{g} / \mathrm{mL}\end{array}$ & $\begin{array}{c}\mathbf{M} \\
(\mathbf{m A U})\end{array}$ & RSD\% & $\begin{array}{c}\mathbf{M} \\
(\mathbf{m A U})\end{array}$ & RSD\% \\
\hline & \multicolumn{2}{|c|}{ Intra-day } & \multicolumn{2}{|c|}{ Inter-day } & & \multicolumn{2}{|c|}{ Intra-day } & \multicolumn{2}{|c|}{ Inter-day } & & \multicolumn{2}{|c|}{ Intra-day } & \multicolumn{2}{|c|}{ Inter-day } \\
\hline 3.12 & 290089 & 0.53 & 286448 & 0.30 & 3.12 & 522244 & 0.12 & 526425 & 0.09 & 1.00 & 75562 & 0.08 & 75205 & 0.11 \\
\hline 25.00 & 2397283 & 0.45 & 2331330 & 0.59 & 25.00 & 4235408 & 0.40 & 4217754 & 0.10 & 8.00 & 572206 & 0.16 & 570656 & 1.03 \\
\hline 100.00 & 9459740 & 0.21 & 9423086 & 0.18 & 75.00 & 12892719 & 0.25 & 12818793 & 0.11 & 20.00 & 1356898 & 0.38 & 1357430 & 0.44 \\
\hline
\end{tabular}

[ ] = concentration; $\mathrm{M}(\mathrm{mAU})$ mean of absorbance $(\mathrm{n}=3)$; RSD $\%$ = relative standard deviation.

Table 2. Results of the evaluation of the accuracy of the new analysis method for quantification of bioactive neolignans eupomatenoid-5, eupomatenoid-6 and conocarpan in crude extract of Piper rivinoides Kunth.

\begin{tabular}{|c|c|c|c|c|c|c|c|c|c|c|c|}
\hline \multicolumn{4}{|c|}{ Eupomatenoid-5 } & \multicolumn{4}{|c|}{ Eupomatenoid-6 } & \multicolumn{4}{|c|}{ Conocarpan } \\
\hline $\begin{array}{c}\text { [] nominal } \\
\mu \mathrm{g} / \mathrm{mL}\end{array}$ & $\begin{array}{c}\text { [ ] calculated } \\
\mu \mathrm{g} / \mathrm{mL}\end{array}$ & $\Delta \mu \mathrm{g} \%$ & $\Delta \%$ & $\begin{array}{c}\text { [] nominal } \\
\mu \mathrm{g} / \mathrm{mL}\end{array}$ & $\begin{array}{c}\text { [ ] calculated } \\
\mu \mathrm{g} / \mathrm{mL}\end{array}$ & $\Delta \mu \mathrm{g} \%$ & $\Delta \%$ & $\begin{array}{c}\text { [ ] nominal } \\
\mu \mathrm{g} / \mathbf{m L}\end{array}$ & $\begin{array}{c}\text { [ ] calculated } \\
\mu \mathrm{g} / \mathrm{mL}\end{array}$ & $\Delta \mu \mathrm{g} \%$ & $\Delta \%$ \\
\hline 100.00 & 99.71 & -0.29 & 99.7 & 75.00 & 74.99 & -0.01 & 99.90 & 20.00 & 19.78 & -1.10 & 98.90 \\
\hline 50.00 & 48.85 & -2.29 & 97.7 & 50.00 & 49.27 & -1.45 & 98.50 & 10.00 & 10.35 & 3.44 & 103.40 \\
\hline 25.00 & 24.45 & -2.22 & 97.7 & 25.00 & 24.56 & -1.75 & 98.20 & 8.00 & 8.17 & 2.08 & 102.00 \\
\hline 12.50 & 11.96 & -4.30 & 95.7 & 12.50 & 12.16 & -2.68 & 97.30 & 4.00 & 4.00 & -0.10 & 99.90 \\
\hline 6.25 & 5.82 & -6.87 & 93.1 & 6.25 & 6.02 & -3.75 & 96.20 & 2.00 & 1.92 & -4.20 & 95.80 \\
\hline 3.12 & 2.75 & -12.00 & 88.9 & 3.12 & 2.92 & -6.61 & 93.30 & 1.00 & 0.86 & -13.59 & 86.40 \\
\hline
\end{tabular}

[ ] = concentration; $\mathrm{M}(\mathrm{mAU})$ mean of absorbance $(\mathrm{n}=3) ; \Delta \%=$ difference in percentage; $\Delta \mu \mathrm{g} \%=$ difference in concentration; [ ] calculated $\mu \mathrm{g} / \mathrm{mL}=$ concentration calculated from the analytical curve formula described in table 2 


\subsection{Limit of quantification (LOQ) and detection (LOD)}

The LOQ and LOD determined for EUP-5, EUP-6 and CNC neolignans were $50.00 \mathrm{ng} / \mathrm{mL}, 50.00 \mathrm{ng} / \mathrm{mL}$ and $100.00 \mathrm{ng} / \mathrm{mL} ; 25.00 \mathrm{ng} / \mathrm{mL}, 25.00 \mathrm{ng} / \mathrm{mL}$ and $37.50 \mathrm{ng} /$ $\mathrm{mL}$, respectively. These data demonstrate that the sensitivity of the method is adequate for the proposed objective and are compatible with a UV detector that can quantify up to the nanogram scale $\left(10^{-9}\right)$.

All chromatographic parameters obtained for each of the signals corresponding to the three neolignans were considered satisfactory, showing that the chromatographic conditions selected for the analytical method in this work are suitable for quantification of bioactive compounds in the crude hydroethanolic extract of $P$. rivnioides.

\section{Quantification}

With the analytical curves for each neolignan, and applying the formulas obtained by linear regression, the percentage content of each compound in the crude hydroalcoholic extracts was calculated. The results of HPLC-DAD quantification of neolignans EUP-5, EUP-6 and $\mathrm{CNC}$ in $P$. rivinoides samples are shown in Table 5.
The EUP-5 content in the hydroalcoholic extract from leaves of $P$. rivinoides was the highest $(3.39-3.87 \%)$, followed by EUP-6 $(0.76-1.39 \%)$ and CNC $(0.10-0.27 \%)$. It is interesting to note that the percentage content of EUP-5 did not change in the months, that represent summer (January), autumn (April) and winter (July) from South hemisphere. Different results was obtained for EUP-6 and CNC. A seasonal study should be done to achieve better collection time to obtain these three bioactive neolignans in great amounts.

A previous study described the development and validation of a method to quantify conocarpan, EUP-5 and EUP-6 in Piper regnellis hydroalcoholic extract. ${ }^{31}$ The method consists of an analysis with a total time of $25 \mathrm{~min}$, in an isocratic elution system, in a mobile phase composed of acetonitrile and acidified water (60:40 v/v). However, data regarding the validation of the EUP-5 and EUP-6 were not described. Thus, the method developed and validated in this work is much more efficient because it presented the validation parameters for three bioactive neolignans, in addition to the shorter analysis time. Another advantage of the newly developed and validated method is the LOD $(<$ $25 \mathrm{ng} / \mathrm{mL})$ and LOQ $(<50 \mathrm{ng} / \mathrm{mL})$, which allow analyzing samples with low concentrations of neolignans, in contrast to the previously published method, which showed limits in the range of $\mathrm{mg} / \mathrm{mL}$, therefore about 1,000 times less sensitive. ${ }^{31}$

Table 3. Results obtained in the recovery analysis of the new analytical method for the quantification of bioactive neolignans eupomatenoid-5, eupomatenoid-6 and conocarpan in crude hydroethanolic extract of $P$. rivinoides Kunth.

\begin{tabular}{ccccc}
\hline Neolignan & {[] $\boldsymbol{\mu g} / \mathbf{m L}$} & M (mAU) & Recovery $(\%)$ & RSD $(\%)$ \\
\hline \multirow{2}{*}{ Eupomatenoid-5 } & 6.25 & 2944139 & 104.10 & 1.20 \\
& 50.00 & 6913714 & 93.10 & 0.30 \\
Eupomatenoid-6 & 6.25 & 3723795 & 89.20 & 1.40 \\
Conocarpan & 50.00 & 11797018 & 100.50 & 2.20 \\
& 2.00 & 292829 & 88.20 & 1.90 \\
\end{tabular}

[] = concentration; $\mathrm{M}(\mathrm{mAU})$ mean of absorbance $(\mathrm{n}=3) ; \mathrm{RSD} \%=$ relative standard deviation

Table 4. Results of the robustness test and its effects on the absorbance of eupomatenoid-5, eupomatenoid-6 and conocarpan caused by the variation of the conditions of the analytical method.

\begin{tabular}{|c|c|c|c|c|c|c|c|c|c|c|c|c|}
\hline \multicolumn{5}{|c|}{ Eupomatenoid-5 } & \multicolumn{4}{|c|}{ Eupomatenoid-6 } & \multicolumn{4}{|c|}{ Conocarpan } \\
\hline \multirow[t]{2}{*}{ Parameters } & \multicolumn{2}{|c|}{ [ ] $3.12 \mu \mathrm{g} / \mathrm{mL}$} & \multicolumn{2}{|c|}{ [ ] $100.00 \mu \mathrm{g} / \mathrm{mL}$} & \multicolumn{2}{|c|}{ [ ] $3.12 \mu \mathrm{g} / \mathrm{mL}$} & \multicolumn{2}{|c|}{ [ ] $75.00 \mu \mathrm{g} / \mathrm{mL}$} & \multicolumn{2}{|c|}{ [ ] $1.00 \mu \mathrm{g} / \mathrm{mL}$} & \multicolumn{2}{|c|}{ [ ] $20.00 \mu \mathrm{g} / \mathrm{mL}$} \\
\hline & M mAU & RSD \% & M mAU & RSD\% & M mAU & RSD\% & M mAU & RSD\% & M mAU & RSD\% & M mAU & RSD\% \\
\hline Nominal & 288583 & 0.04 & 9454758 & 0.17 & 522297 & 0.37 & 12855605 & 0.22 & 75625 & 0.45 & 1352663 & 0.15 \\
\hline $\operatorname{var} \mathbf{A}$ & 284993 & 1.31 & 9426219 & 0.15 & 528043 & 0.41 & 12889256 & 0.84 & 75712 & 0.34 & 1362517 & 0.64 \\
\hline $\operatorname{var} B$ & 277769 & 1.92 & 9454922 & 0.13 & 521014 & 0.22 & 12926261 & 0.13 & 75561 & 0.43 & 1361942 & 0.09 \\
\hline $\operatorname{var} C$ & 273727 & 0.11 & 9448722 & 0.49 & 523886 & 0.49 & 12904317 & 0.11 & 75830 & 0.18 & 1367896 & 0.75 \\
\hline $\operatorname{var} D$ & 283819 & 0.64 & 9416997 & 0.21 & 522050 & 0.10 & 12917169 & 0.17 & 75897 & 0.25 & 1370097 & 0.08 \\
\hline $\operatorname{var} E$ & 270448 & 1.99 & 9465719 & 0.18 & 521488 & 0.04 & 12943338 & 0.26 & 75787 & 0.76 & 1367719 & 0.69 \\
\hline Mean & 279890 & 2.52 & 9444556 & 0.20 & 523130 & 0.50 & 12905991 & 0.24 & 75735 & 0.17 & 1363806 & 0.46 \\
\hline
\end{tabular}

Nominal condition: flow rate at $1.0 \mathrm{~mL} / \mathrm{min}$; oven temperature at $50{ }^{\circ} \mathrm{C}$; acetonitrile (Tedia Brazil ${ }^{\varpi}$ ) in the mobile phase by $80 \%$; wavelength at $256 \mathrm{~nm}(\mathrm{EUP}-5$ and EUP-6), $264 \mathrm{~nm}(\mathrm{CNC})$; Variations $\rightarrow$ A: $0.8 \mathrm{~mL} / \mathrm{min}$ flow rate; B: oven temperature at $48{ }^{\circ} \mathrm{C}$; C: acetonitrile in the mobile phase $78 \%$; D: Wavelength 258nm (EUP-5 and EUP-6) 266nm (CNC); E: acetonitrile Merck brand; $\mathrm{M}=\mathrm{mAU}=$ mean of absorbance $(\mathrm{n}=3)$; RSD $\%=$ relative standard deviation. 
Table 5. Quantification of eupomatenoid-5, eupomatenoid-6 and conocarpan by HPLC-DAD in Piper rivinoides samples.

\begin{tabular}{ccccccc}
\hline \multirow{2}{*}{ Sample } & \multicolumn{2}{c}{ Eupometenoid-5 } & \multicolumn{2}{c}{ Eupomatenoid-6 } & \multicolumn{2}{c}{ Conocarpan } \\
& Content* $(\boldsymbol{\mu g} / \mathbf{m L})$ & $\%(\mathbf{w} / \mathbf{w})$ & Content $(\boldsymbol{\mu g} / \mathbf{m L})$ & $\boldsymbol{\%}(\mathbf{w} / \mathbf{w})$ & Content $(\boldsymbol{\mu g} / \mathbf{m L})$ & $\%(\mathbf{w} / \mathbf{w})$ \\
\hline January & $383.63 \pm 3.25$ & 3.80 & $76.25 \pm 1.16$ & 0.76 & $10.12 \pm 0.17$ & 0.10 \\
April & $386.73 \pm 3.68$ & 3.87 & $138.63 \pm 1.64$ & 1.39 & $13.86 \pm 3.58$ & 0.14 \\
July & $339.56 \pm 0.73$ & 3.39 & $109.20 \pm 0.28$ & 1.09 & $27.63 \pm 0.24$ & 0.27 \\
\hline
\end{tabular}

\section{Conclusions}

The new developed and validated analytical method using HPLC-DAD in isocratic mode allowed the simultaneous detection and quantification of bioactive benzofuran neolignans EUP-5, EUP-6 and CNC in crude extracts of $P$. rivinoides. The validation of the method demonstrated its reliability by selectivity, linearity, precision, accuracy, recovery and robustness. The method proved to be reproducible, fast, and economical. Thus, the results obtained in this study contribute to set the parameters for the quality control of $P$. rivinoides extracts.

\section{Acknowledgements}

The authors are grateful to FAPERJ (E-26/202.617/2018) for providing the scholarship to the first author and to PROEP-CNPq (407845/2017-8) for financial support.

\section{References}

1. Flora do Brasil 2020 em construção. Jardim Botânico do Rio de Janeiro. Disponível em: <http://floradobrasil.jbrj.gov.br/>. Acesso em: 25 Junho 2020.

2. Queiroz, G. A.; Barros, A. A. M.; Guimarães, E. F.; Piper (Piperaceae) from Serra da Tiririca State Park, Niterói/Maricá, RJ, Brazil. Rodriguésia 2020, 71. [CrossRef]

3. Barros, J. F. P.; Napoleão, E.; Ewé òrìsà: uso litúrgico e terapêutico dos vegetais nas casas de candomblé Jêje-Nagô. Bertrand Brasil: Rio de Janeiro, 2003.

4. Barros, A. J.; Ossaim O Orixá E Nossos Chás Volume Único. Clube de Autores: São Paulo, 2010.

5. Mandarino, A. C.; Gomberg, E.; Água e ancestralidade Jeje-Nagô: possibilidade de existências. Textos de história 2009, 17, 143. [Link]

6. Albuquerque, U. P.; Monteiro, J. M.; Ramos, M. A.; Amorim, E. L. C.; Medicinal and magic plants from a public market in northeastern Brazil. Journal of Ethnopharmacology 2007, 110, 1. [CrossRef]

7. Perigo, C. V; Torres R. B.; Bernucci L. C.; Guimarães E. F.; Haber L. L.; Facanali, R.; Vieira, M. A. R.; Quecini, V.; Marques M. O.; The chemical composition and antibacterial activity of eleven Piper species from distinct rainforest areas in Southeastern Brazil. Industrial Crops and Production 2016, 94, 528. [CrossRef]
8. Bernuci, K; Iwanaga, C; Fernandez-Andrade, C.; Lorenzetti, F. B.; Torres-Santos, E. C.; Evaluation of chemical composition and antileishmanial and antituberculosis activities of essential oils of Piper species. Molecules 2016, 21, 12. [CROSSREF]

9. Moreira, D. L.; Paiva, R. A.; Marques A. M.; Borges, R. M.; Barreto, A. L. S; Curvelo, A. R.; Cavalcanti, J. F.; Kaplan, M. A.; Bioactive Neolignans from the Leaves of Piper rivinoides Kunth (Piperaceae). Records of Natural Products 2016, 10, 4724. [LINK]

10. Leal, A. L.; Machado, A. J. T.; Bezerra, C. F; Inácio, C. E. S.; Rocha, J. E.; Sales D. L.; Freitas, T. S.; Almeida, W. O.; Amaral, W.; Coutinho, H. D. M.; Chemical identification and antimicrobial potential of essential oil of Piper rivinoides kunth (BETIS-WHITE). Food and Chemical Toxicology 2019, 131, 110559. [CrossRef]

11. Souza, S., P.; Valverde, S. S.; Costa, N. F.; Calheiros, A. S.; Lima, K. S. C.; Frutoso, V. S.; Lima, A. L. S.; Chemical composition and antinociceptive activity of the essential oil of Piper mollicomum and Piper rivinoides. Journal of Medicinal Plant Research 2014, 8, 22. [CrossRef]

12. Fonseca, A. C. C.; Queiroz L. N.; Felisberto, J. S. Ramos, Y. J. Marques A. M.; Cytotoxic effect of pure compounds from piper rivinoides kunth against oral squamous cell carcinoma. Natural Products Research 2020, 1. [CrossRef]

13. Scodro, R. B. L.; Pires C. T. A.; Carrara V. S.; Lemos, C. O. T.; Cardozo-Filho L.; Souza, V. A.; Corrêa, A. G; Siqueira, V. L. D, Cardoso R. F.; Cortez D. A. G.; Anti-tuberculosis neolignans from Piper regnellii. Phytomedicine 2013, 20, 7. [CrossRef] [PubMed]

14. Ghiraldi-Lopes, L. D.; Campanerut-Sá, P. A.; Meneguello, J. E. Proteomic profile of Mycobacterium tuberculosis after eupomatenoid-5 induction reveals potential drug targets. Future Microbiology 2019, 12, 10. [CrossRef]

15. Jaidee, W.; Maneerat, W; Andersen, R. J.; Patrick, B. O.; Pyne, S. G.; Laphookhieo, S.; Antioxidant neolignans from the twigs and leaves of Mitrephora wangii HU. Fitoterapia 2018, 130, 219. [CrossRef]

16. Garcia, F. P.; Lazarin-Bidóia, D.; Ueda-Nakamura, T. Eupomatenoid-5 Isolated from Leaves of Piper regnellii Induces Apoptosis in Leishmania amazonensis. Evid.-Based Complementary Alterna. Med. 2013. [CrossRef]

17. Vendrametto, M. C.; Santos A. O.; Nakamura C. V.; Dias-Filho, B. P; Cortez, D. A. G; Ueda-Nakamura, T. Evaluation of antileishmanial activity of eupomatenoid-5, a compound isolated from leaves of Piper regnellii var. pallescens. Parasitol. Int.l 2010, 59, 2, 154-158. [CrossRef]

18. Longato, G. B.; Rizzo, L. Y; Sousa, I. M. In vitro and In vivo Anticancer Activity of Extracts, Fractions, and Eupomatenoid-5 Obtained from Piper regnellii Leaves. Planta Médica 2011, 77, 13. 
19. Pelizzaro-Rocha, K. J.; Veiga-Santos B. P.; Lazarin-Bidóia, D. Trypanocidal action of eupomatenoid-5 is related to mitochondrion dysfunction and oxidative damage in Trypanosoma cruzi. Microb. Infect. 2019, 13, 12-13. [CrossRef]

20. Lazarin-Bidóia, D.; Desoti, V.; Ueda-Nakamura, T. Dias-Filho B.P; Nakamura, C.V; Silva, S. O. Further evidence of the trypanocidal action of eupomatenoid-5: Confirmation of involvement of reactive oxygen species and mitochondria owing to a reduction in trypanothione reductase activity. Free Radic. Biol. Med. 2013, 60, 17-28. [CrossRef]

21. Macedo, A. L.; Duprat, R.C.; Moreira, D.L; Kaplan, M. A.; Vasconcelos, T. R.; Pinto, L.C.; Montenegro, R.C.; Isolation of a larvicidal compound from Piper solmsianum C. DC. (Piperaceae). Nat. Prod. Res. 2018, 32, 22. [CrossRef]

22. Ortiz, S.; Lecsö-Bornet, M.; Bonnal, C.; Houze, S.; Michel, S.; Grougnet, R.; Boutefnouchet, S. Bioguided identification of triterpenoids and neolignans as bioactive compounds from antiinfectious medicinal plants of the Taira Atacama's community (Calama, Chile). J. Ethnopharmacol. 2018, 231. [CrossRef]

23. Pessini, G. L.; Filhoii, B. P.; Nakamura, C. V.; Cortez, A.G. Antifungal activity of the extracts and neolignans from Piper regnellii (Miq.) C. DC. var. pallescens (C. DC.) Yunck. Journal of the J. Braz. Chem. Soc. 2005, 16, 6. [CrossRef]

24. Xu, W.; Li, X. Antifungal Compounds from Piper Species. Curr. Bioact. Compd 2011, 7, 4. [
25. Lemos, C. O. T.; Garcia, V. A. S.; Gonçalves, R. M.; Leal, I. C. R.; Siqueira, V. L. D. Cabral, V. F. Supercritical extraction of neolignans from Piper regnelli var. pallescens. J. Superc. Fluid. 2002, 71. [CrossRef]

26. Da Silva, R. Z.; Yunes, R. A.; Souza, M.; Monache, F. D. CechinelFilho, V. Antinociceptive properties of conocarpan and orientin obtained from Piper solmsianum C. DC. var. solmsianum (Piperaceae). J.Nat. Medic. 2010, 64, 4. [CrossRef]

27. BRASIL - ANVISA. Agência Nacional de Vigilância Sanitária. Resolução da Diretoria Colegiada - RDC No 166 de 24 de julho de 2017. Guia para validação de métodos analíticos.

28. Azmir, J.; Zaidul, I. S. M.; Rahman M. M.; Mohamed A.; Omar, A. K. M. Techniques for extraction of bioactive compounds from plant materials: A review. J. Food Engineer. 2013, 117, 4, 426-436. [CrossRef]

29. INMETRO - Instituto Nacional de Metrologia, Qualidade e Tecnologia. DOQ-CGCRE-008 - Orientação sobre validação de Métodos analíticos. Revisão 05, 2016.

30. Guideline, ICH Harmonised Tripartite. Validation of analytical procedures: text and methodology $Q 2(R 1)$. In: International conference on harmonization, Geneva, Switzerland, 2005.

31. Felipe, D. F.; Dias-Filho, B. P.; Nakamura, C. V.; Franco, S. L.; Cortez, D. A. G. Analysis of neolignans compounds of Piper regnellii (Miq.) C. DC. var. pallescens (C. DC.) Yunck by HPLC. J. pharm. Biome. Anal. 2006, 41, 4 1371-1375. [CrossRef] 